NLCO - 881

Metals, Ceramics and Materials

(TID - 4500, 20th Ed.)

\title{
ELECTRON BEAM MELTING OF URANIUM
}

\section{By}

H. M. Eikenberry

of

TECHNICAL DIVISION

NATIONAL LEAD COMPANY OF OHIO

Date of Issuance: June 14, 1963

Approved By:

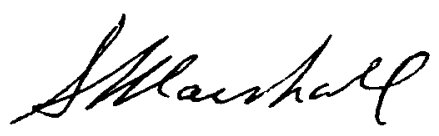

Technical Director
Approved By:

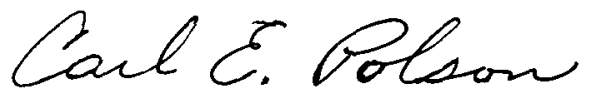

Head, Metallurgical Department 


\section{DISCLAIMER}

This report was prepared as an account of work sponsored by an agency of the United States Government. Neither the United States Government nor any agency Thereof, nor any of their employees, makes any warranty, express or implied, or assumes any legal liability or responsibility for the accuracy, completeness, or usefulness of any information, apparatus, product, or process disclosed, or represents that its use would not infringe privately owned rights. Reference herein to any specific commercial product, process, or service by trade name, trademark, manufacturer, or otherwise does not necessarily constitute or imply its endorsement, recommendation, or favoring by the United States Government or any agency thereof. The views and opinions of authors expressed herein do not necessarily state or reflect those of the United States Government or any agency thereof. 


\section{DISCLAIMER}

Portions of this document may be illegible in electronic image products. Images are produced from the best available original document. 
The work reported herein was performed under the direction of

H. Davis

Supervisor, Process Metallurgy 


\section{CONTENTS}

Page No.

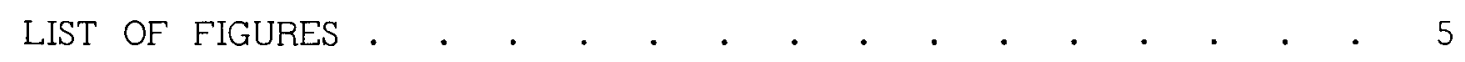

ABSTRACT . . . . . . . . . . . . . . . . . . 7

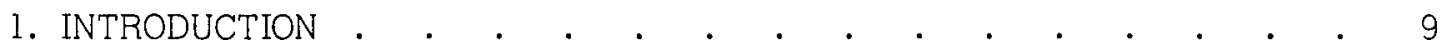

2. PURPOSE . . . . . . . . . . . . . . . . . . . 9

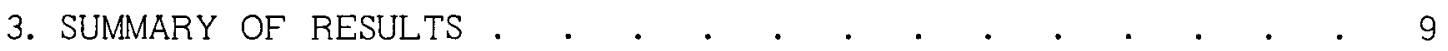

3.1 Removal of Contaminants . . . . . . . . . . . . . . 9

3.2 Melting Rates and Procedures . . . . . . . . . . . 10

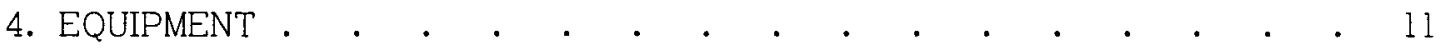

5. PROCEDURES . . . . . . . . . . . . . . . . . 13

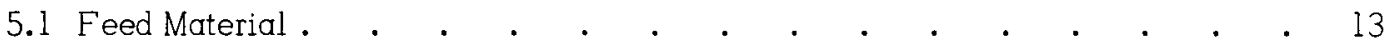

5.2 Feed Preparation . . . . . . . . . . . . . . . . . 14

5.3 Melting Procedure . . . . . . . . . . . . . . 15

6. RESULTS AND DISCUSSION • . . . . . . . . . . . . . 17

6.1 Melting . . . . . . . . . . . . . . . . 17

6.2 Metallography. . . . . . . . . . . . . . . 18

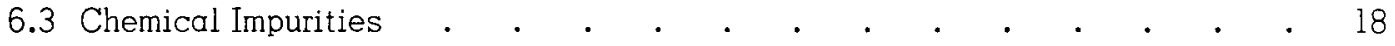

7. CONCLUSIONS . . . . . . . . . . . . . . . . . . 27

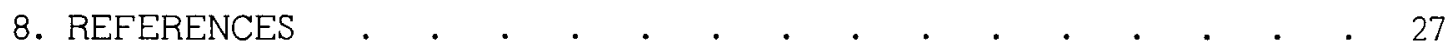


$-4-$

(

4

$\checkmark$

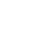

$\bullet$ 


\section{LIST OF FIGURES}

Figure No.

Page No.

Uranium Feedstock Suspended by Tantalum Wire Over Electron Beam

Gun .

Uranium Feedstock Suspended by Tantalum Wire Over Ingot Puller Cup with Gun Retracted

Grain Structure and Inclusions in Longitudinal Center Sections of Electron-Beam-Melted Dingot Uranium . . . . . .

Grain Structure and Inclusions in Longitudinal Center Sections of Electron - Beam - Melted Pigot Uranium

Grain Structure and Inclusions in Longitudinal Center Sections of

Electron-Beam -Melted Ingot Uranium

Edge and Center of Inclusions of Electron-Beam-Melted Dingot

Uranium . 
$-6-$

$\theta$ 


\begin{abstract}
Feed stock prepared from ingot, dingot, and under-salt-melted uranium was melted by electron bombardment. Analysis of the ingots produced revealed that some aluminum, chromium, magnesium, manganese, and lead were volatilized from the melt. Carbon was reduced when zirconium was present in the feed material. Hydrogen and nitrogen also were removed, the latter only when there was a relatively high concentration in the feed material. The work indicated the need for very slow melting rates or the casting of large diameter ingots for successful refinement of uranium.
\end{abstract}


$-8-$

$\bullet$ 


\section{INTRODUCTION}

The interest expressed by the production reactor sites in obtaining uranium fuel cores of higher purity has led the National Lead Company of Ohio to undertake a number of studies aimed at promoting a more complete understanding of some of the factors influencing metal quality.

An investigation of the effects of furnace operating pressure on the quality of ingots produced in a vacuum induction furnace ${ }^{l}$ showed that (1) the hydrogen concentration in the ingot is directly related to the furnace pressure, (2) ingot carbon is inversely related to the furnace operating pressure, and (3) at pressures above 3 torr ( $\mathrm{mm}$ of $\mathrm{Hg}$ ), ingot nitrogen is directly related to the furnace pressure.

In another study, uranium electrodes were arc-melted under vacuum. ${ }^{2}$ An analysis of the uranium ingots produced showed that the carbide impurities were more finely distributed throughout the ingot when compared with ingots produced by vacuum induction melting.

Since electron beam furnaces have become available in production size and are designed to operate at lower pressures than those employed in vacuum induction and consumable-electrode arc melting, it was thought advisable to also investigate this means of melting uranium.

\section{PURPOSE}

The purposes of melting uranium in an electron beam furnace were:

1. To determine the extent of removal of impurities from uranium under an atmosphere of $10^{-4}$ to $10^{-5}$ torr using electron bombardment as the heating source.

2. To establish drip-melting rates and procedures.

\section{SUMMARY OF RESULTS}

Twelve ingots were produced by electron beam melting, four each from dingot, ingot, and pigot feed material. Six of these ingots were melted a second time for a total of 18 melts. The ingots were 3 inches in diameter by 8 inches long and weighed approximately 40 pounds each. They were evaluated by metallographic and analytical techniques.

\subsection{REMOVAL OF CONTAMINANTS}

The hydrogen concentration decreased in all ingots produced by electron bombardment. Chemical analyses showed that the concentrations of aluminum, chromium, magnesium, manganese, and lead in the electron-beam-melted metal were less than in the feed material. 
$-10-$

The nitrogen concentration was reduced when the feed material was relatively high (over $100 \mathrm{ppm}$ ) in this impurity.

Carbon was reduced in those ingots in which zirconium was contained in the feed material.

\subsection{MELTING RATES AND PROCEDURES}

A maximum melting rate of 22 inches per hour was established. Half of each type of the ingots produced were melted at this rate, and the remainder at approximately $50 \%$ of this rate. 


\section{EQUIPMENT}

The electron beam furnace used in these tests was located in the Stauffer Metals Company's beryllium laboratory in Richmond, California. A detailed description of the furnace (Figure 1) and the electron beam process has been given by Smith, Hunt, and Hanks. ${ }^{3}$

$1033 \cdot 1$

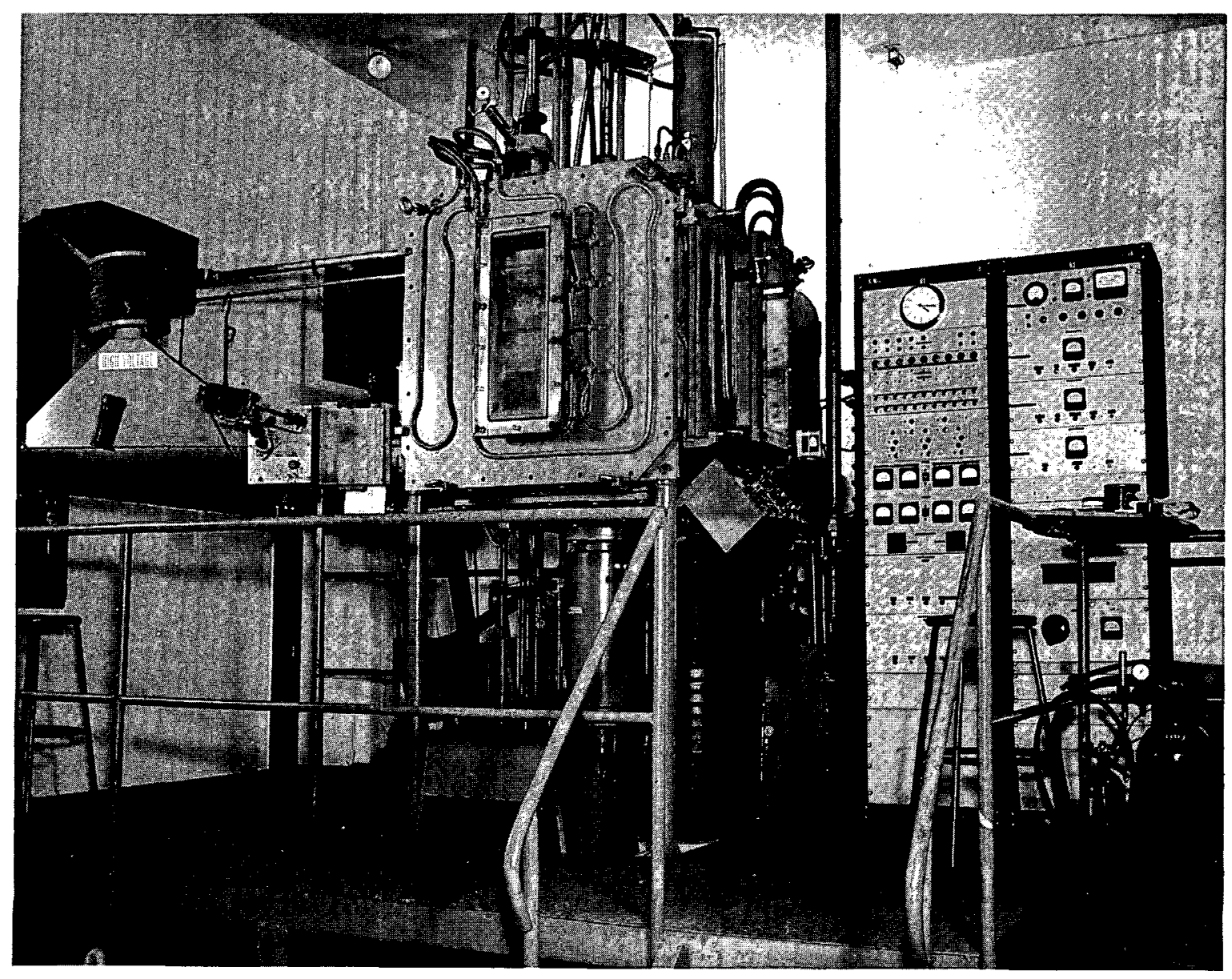

FIGURE 1 Electron Beam Furnace

A 3-inch, water-cooled, copper crucible was used. An extraction device was incorporated into the crucible to retract the solidifying ingot during the melting operation. The power supply was rated at $30 \mathrm{kw}$. The operating voltage was 5 to $10 \mathrm{kv}$. The vacuum system included a 20 -inch oil diffusion pump with a capacity of 7000 liters per second backed up by a 500-liters-persecond oil jet pump. The forepump was a $113 \mathrm{cfm}$ Kinney mechanical pump. 
$-12-$

$\bullet$

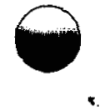




\section{PROCEDURES}

\subsection{FEED MATERIAL}

Dingot, ingot, and pigot (under-salt-melted uranium) metal were the three types of feed material prepared for electron beam melting. The average chemical analyses of the three types are given in Table I.

TABLE I Average Chemical Analyses of the Feed Material and Electron-Beam Melted Ingots

\begin{tabular}{|c|c|c|c|c|c|c|}
\hline \multirow[b]{2}{*}{ Element } & \multicolumn{2}{|c|}{ Feed Material } & \multicolumn{4}{|c|}{$\begin{array}{c}\text { Electron-Beam-Melted Ingots } \\
\text { (Avg Analyses, ppm) }\end{array}$} \\
\hline & Type & $\begin{array}{c}\text { Average } \\
\text { Analyses } \\
\text { (ppm) }\end{array}$ & $\begin{array}{l}\text { Melting } \\
\text { Rate } \\
\text { Slow }\end{array}$ & $\begin{array}{c}\text { Melting } \\
\text { Rate } \\
\text { Fast }\end{array}$ & $\begin{array}{l}\text { Melted } \\
\text { Once }\end{array}$ & $\begin{array}{l}\text { Melted } \\
\text { Twice }\end{array}$ \\
\hline \multirow{3}{*}{$\mathrm{H}_{2}$} & Dingot & 2.77 & 0.17 & 0.50 & 0.42 & 0.25 \\
\hline & Ingot & 1.46 & 0.72 & 0.57 & 0.66 & 0.63 \\
\hline & Pigot & 2.52 & 0.31 & 0.50 & 0.56 & 0.25 \\
\hline \multirow{3}{*}{$\mathrm{N}_{2}$} & Dingot & 19 & 17 & 20 & 19 & 19 \\
\hline & Ingot & 112 & 54 & 58 & 53 & 58 \\
\hline & Pigot & 31 & 26 & 26 & 29 & 22 \\
\hline \multirow{3}{*}{$\mathrm{O}_{2}$} & Dingot & 22 & 18 & 28 & 22 & 25 \\
\hline & Ingot & 94 & 67 & 57 & 69 & 55 \\
\hline & Pigot & 64 & 25 & 15 & 25 & 15 \\
\hline \multirow{3}{*}{ C } & Dingot & 10 & 40 & 20 & 28 & 31 \\
\hline & Ingot & 748 & 688 & 672 & 712 & 655 \\
\hline & Pigot & 271 & 284 & 295 & 286 & 291 \\
\hline \multirow{3}{*}{$\mathrm{Zr}$} & Dingot & 5 & 5 & 5 & 5 & 5 \\
\hline & Ingot & 67 & 53 & 46 & 60 & 38 \\
\hline & Pigot & 5 & 5 & 5 & 5 & 5 \\
\hline \multirow{3}{*}{$\mathrm{Al}$} & Ding ot & 27 & 22 & 20 & 25 & 17 \\
\hline & Ingot & 6 & 6 & 6 & 6 & 6 \\
\hline & Pigot & 13 & 8 & 9 & 9 & 8 \\
\hline \multirow{3}{*}{$\mathrm{Cr}$} & Dingot & 15 & 8 & 11 & 11 & 8 \\
\hline & Ingot & 13 & 8 & 9 & 8 & 8 \\
\hline & Pigot & 9 & $\overline{6}$ & 6 & 6 & 6 \\
\hline \multirow{3}{*}{$\mathrm{Mg}$} & Dingot & 5 & 5 & 5 & 5 & 5 \\
\hline & Ingot & 8 & 5 & 5 & 5 & 5 \\
\hline & Pigot & 70 & 5 & 8 & 9 & 5 \\
\hline \multirow{3}{*}{$M n$} & Dingot & 14 & 5 & 7 & 10 & 6 \\
\hline & Ingot & 130 & 69 & 60 & 61 & 68 \\
\hline & Pigot & 11 & 7 & 6 & 8 & 5 \\
\hline \multirow{3}{*}{$\mathrm{Pb}$} & Dingot & 2 & 2 & 2 & 2 & 2 \\
\hline & Ingot & 2 & 2 & 2 & 2 & 2 \\
\hline & Pigot & 107 & 33 & 41 & 50 & 24 \\
\hline
\end{tabular}

\subsubsection{Dingot}

A 7 -inch-diameter extruded dingot low in carbon, low in oxygen, and high in hydrogen was selected as the dingot feedstock. 


\subsubsection{Ingot}

A 7 -inch-diameter ingot was produced in a vacuum induction furnace. All operating procedures were similar to the plant procedures used to produce reactor-grade uranium except that certain metallic contaminants were added to the crucible before the ingot was poured. The additives were:

1. 18 grams each of $\mathrm{Mn}, \mathrm{Sn}, \mathrm{Cu}$, and $\mathrm{Ni}$.

2. 90 grams Zr.

\subsubsection{Pigot}

A 7 -inch-diameter ingot was produced by melting uranium by induction in air under a salt flux and casting the metal into a graphite mold.

\subsection{FEED PREPARATION}

Each of the 7 -inch ingots was rolled to billet size with an oval cross section $2 \frac{1}{16}$ by $2 \%$ inches. A billet from each ingot was sawed into four pieces, two pieces $14 \frac{1}{2}$-inches long and two pieces 19 -inches long. The short pieces were used as feed to produce single-melted electron beam ingots; the longer pieces were used to produce double-melted ingots. Table II gives the types of feed material and weights of the ingots produced.

TABLE II Material Balance and Average Feed Rates

\begin{tabular}{|c|c|c|c|c|c|c|c|}
\hline $\begin{array}{c}\text { Ingot } \\
\text { No. }\end{array}$ & $\begin{array}{c}\text { Type } \\
\text { of } \\
\text { Feed }\end{array}$ & $\begin{array}{c}\text { Feed } \\
\text { in } \\
(\mathrm{lb})\end{array}$ & $\begin{array}{l}\text { Ingot } \\
\text { out } \\
\text { (lb) }\end{array}$ & $\begin{array}{c}\text { Stub } \\
\text { out } \\
\text { (lb) }\end{array}$ & $\begin{array}{c}\text { Weight } \\
\text { Loss } \\
\text { (lb) }\end{array}$ & $\begin{array}{c}\text { Melting } \\
\text { Rate } \\
\text { (in./hr) }\end{array}$ & Remarks \\
\hline$x-1$ & Dingot & 41.1 & 35.0 & 6.0 & 0.1 & 9 & \\
\hline$x-2$ & \begin{tabular}{|l|} 
Dingot \\
\end{tabular} & 41.2 & 35.2 & 5.8 & 0.2 & 22 & \\
\hline $\mathrm{X}-3$ & Dingot & 54.2 & 48.0 & 5.7 & 0.5 & 9 & First 2 in. melted at rate of $2 \mathrm{in.} / \mathrm{hr}$ \\
\hline $\mathrm{X}-4$ & Dingot & 54.2 & 41.3 & 12.7 & 0.2 & 22 & \\
\hline$X-5^{\star}$ & $\mathrm{X}-3$ & 48.0 & 31.7 & 16.0 & 0.3 & 9 & Melted in 3 sections because of mechanical trouble \\
\hline$x-6^{*}$ & $x-4$ & 41.3 & 25.1 & 16.1 & 0.1 & 22 & \\
\hline$T-7$ & Ingot & 41.2 & 34.9 & 6.1 & 0.2 & 15 & \\
\hline$T-8$ & Ingot & 41.2 & 30.8 & 10.3 & 0.1 & 26 & \\
\hline $\mathrm{T}-9$ & Ingot & 53.8 & 43.7 & 10.1 & 0.0 & 11 & \\
\hline $\mathrm{T}-10$ & Ingot & 53.8 & 42.0 & 11.4 & 0.0 & 22 & First 3 in. melted at $7 \mathrm{in.} / \mathrm{hr}$; last 6 in. at high rate. \\
\hline$T-11^{\star}$ & $T-9$ & 43.7 & 25.2 & 18.4 & 0.1 & $\overrightarrow{24}$ & \\
\hline $\mathrm{T}-12^{\star}$ & $\mathrm{T}-10$ & 42.0 & 33.4 & 8.5 & 0.1 & 25 & \\
\hline$w-13$ & Pigot & 40.9 & 25.7 & 15.0 & 0.2 & 9 & \\
\hline$W-14$ & Pigot & 40.6 & 31.8 & 8.3 & 0.5 & 16 & \\
\hline$W-15$ & Pigot & 53.0 & 41.1 & 11.5 & 0.4 & 15 & \\
\hline$W-16$ & Pigot & 52.8 & 38.4 & 13.8 & 0.6 & 6 & \\
\hline$w-17^{*}$ & $\begin{array}{l}W-15 \\
w-16\end{array}$ & $\begin{array}{l}41.1 \\
38.4\end{array}$ & 40.7 & $\begin{array}{l}18.3 \\
13.7\end{array}$ & 0.8 & 6 & $\begin{array}{l}6 \mathrm{lb} \text { of scrap was produced because of stuck ingot puller. } \\
W-16 \text { was mel ted on top of } W-15 \text { to make ingot } W-17 \text {. }\end{array}$ \\
\hline
\end{tabular}

* Double-melted ingots. 


\subsection{MELTING PROCEDURE}

The uranium feed material was suspended by a tantalum wire from the feed drive rod and centered through the electron-beam gun over the crucible (Figure 2). The furnace was closed and pumped

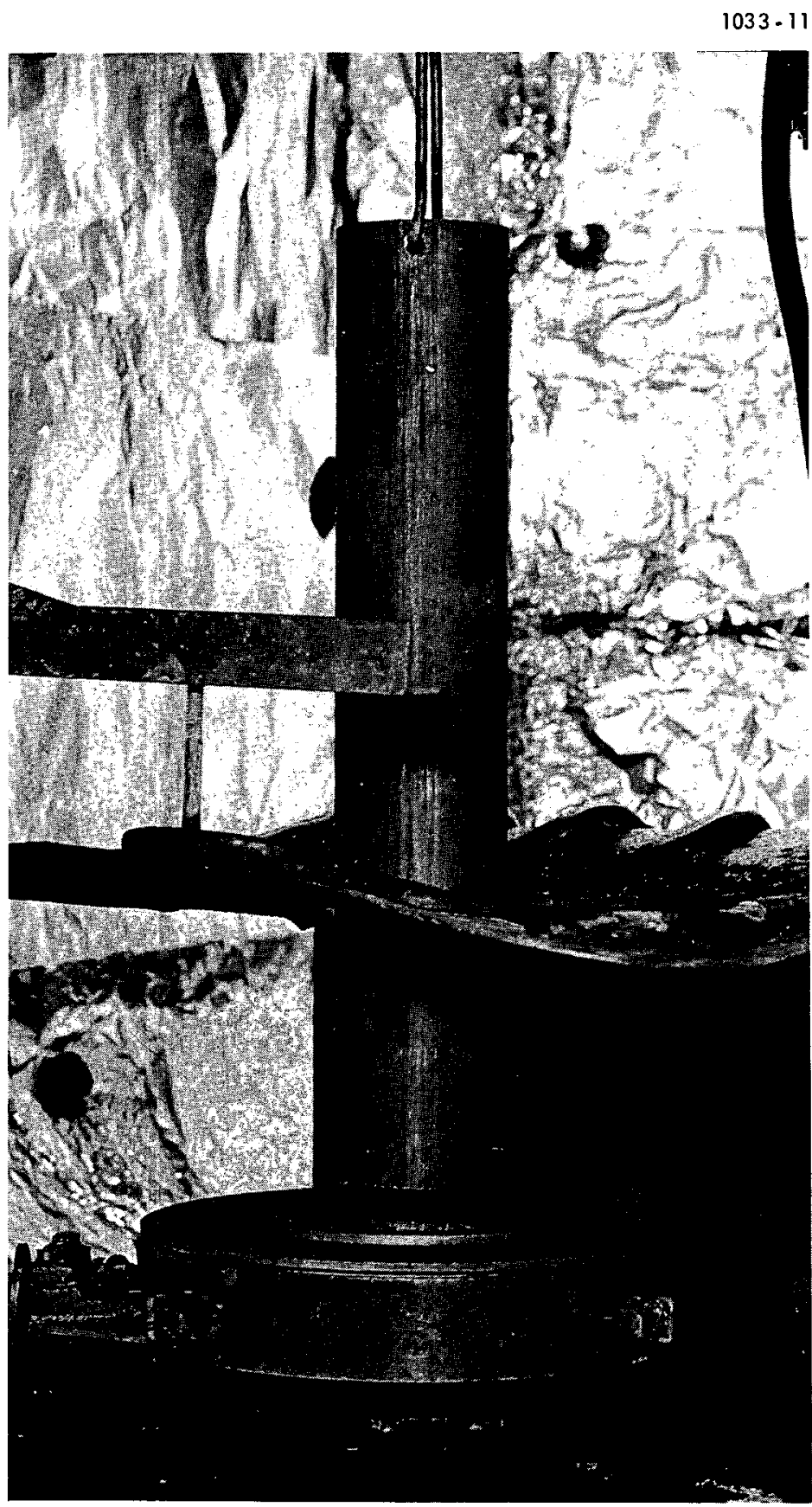

FIGURE 2 Uranium Feedstock Suspended by Tantalum Wire Over Electron Beam Gun 
down to a pressure of $2 \times 10^{-4}$ torr. The filament was heated by 48 volts, ac, at $9 \mathrm{amp}$. The high voltage dc was 5 to $6 \mathrm{kv}$ at 2 to $3 \mathrm{amp}$. The ingot puller cup (Figure 3) was positioned $1 / 2$ to $\mathrm{l}$-inch below the crucible top, and the feed rod was lowered down into the gun where the uranium started to melt.

$1033 \cdot 13$

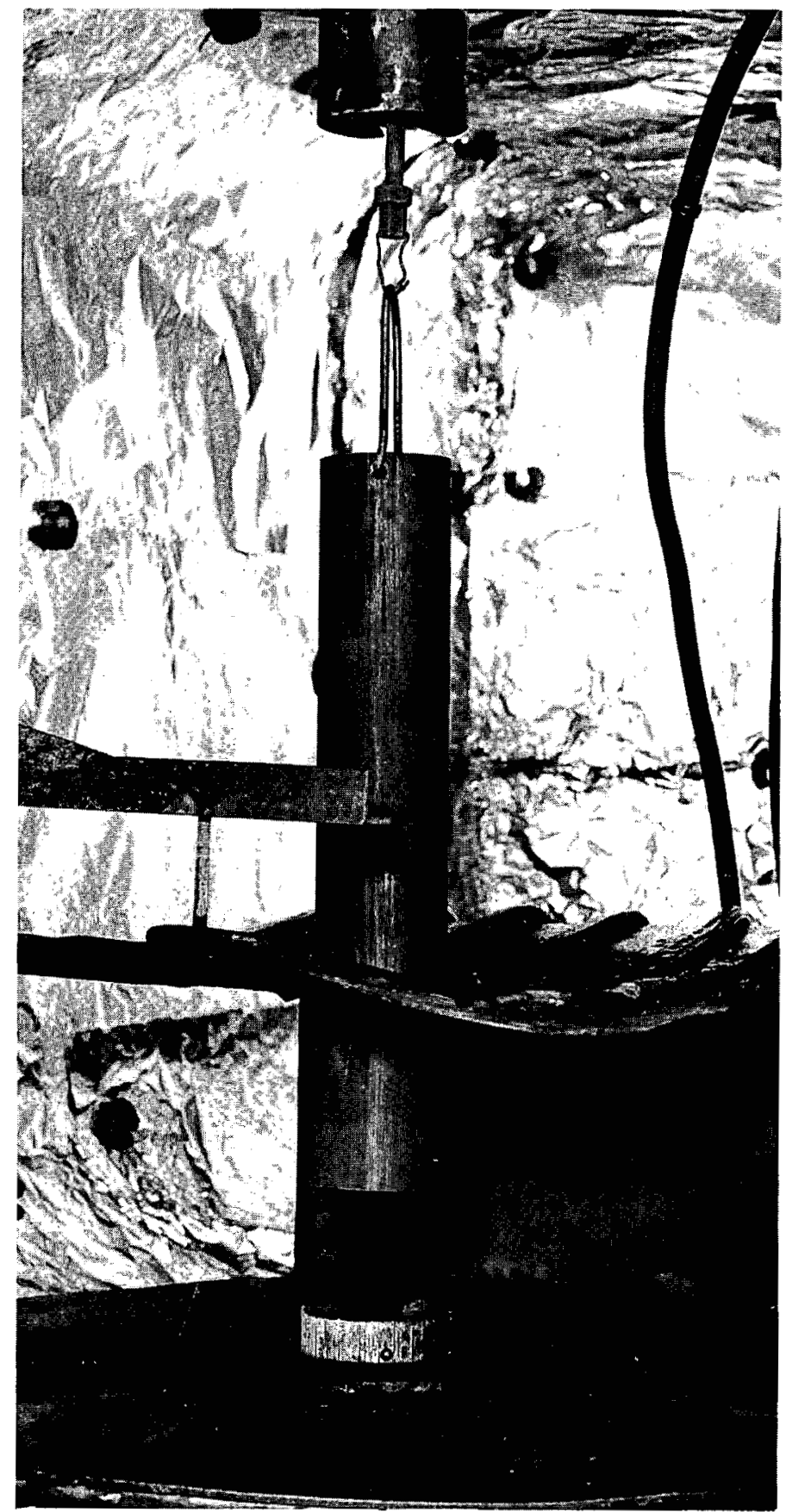

FIGURE 3 Uranium Feedstock Suspended by Tantalum Wire Over Ingot Puller Cup with Gun Retracted 
The beam was focused so that the electrons impinged within the upper crucible area as well as at the end of the feed-rod. Heat radiated from the surface of the melt assisted in heating and melting the end of the feed rod: The uranium melted and dripped into the top of the crucible at a temperature only slightly above the melting point of uranium $\left(1133^{\circ} \mathrm{C}\right.$ or $\left.2072^{\circ} \mathrm{F}\right)$.

As the metal solidified in the crucible, the ingot was pulled from the crucible by the ingot puller mechanism until the melting of the feed material was completed.

The dingot was the first type of feed material melted. The first electron-beam-melted ingot was produced at a rate of $9 \mathrm{in.} / \mathrm{hr}$ and the second at $22 \mathrm{in.} / \mathrm{hr}$. A procedure was then established to produce half the ingots at $22 \mathrm{in.} / \mathrm{hr}$ and the remainder of the ingots at approximately one-half of this rate.

After all the primary and secondary electron-beam-melted ingots were produced, the ingots were returned to the National Lead Company of Ohio for evaluation. Each ingot was cut through the longitudinal center line to determine the segregation of inclusions and voids, and to study the grain structures. Samples were cut from the top, center, and bottom for all chemical analyses, except that a center sample only from each ingot was analyzed for hydrogen.

\section{RESULTS AND DISCUSSION}

\subsection{MELTING}

The melting rates are given in Table II. Observed melting action is summarized below, according to the type of feed material. The loss of metal during melting was due Iargely to spattering during outgassing.

\subsubsection{Dingot Feed Material}

The dingot feed melted relatively easily. Some outgassing was observed. A maximum melting rate of $22 \mathrm{in./hr}$ was obtained with an average weight loss during melting of $0.7 \%$.

\subsubsection{Ingot Feed Material}

The ingot feed material melted relatively easily with little outgassing being observed. A maxi mum feed rate of $26 \mathrm{in./hr}$ was attained. The average metal loss during melting was only $0.2 \%$. 


\subsubsection{Pigot Feed Material}

The pigot feed was the most difficult to melt. The maximum melting rate was $16 \mathrm{in} . / \mathrm{hr}$ with a large amount of outgassing being observed. The average weight loss during melting was $1.4 \%$.

\subsection{METALLOGRAPHY}

Except for those castings made from ingot feed, parentage and prior history had little effect on metallography, as shown in the accompanying photomacrographs. Figures 4 and 5 are photomacrographs of representative sections of ingots produced from dingot and pigot feed. Here $a$ few voids are present. A photomacrograph of a representative section of an ingot produced from the ingot feed material is presented in Figure 6. The layered effect of some of the impurities can be observed, the majority of which are believed to be carbides.

The inclusions observed in samples from ingots produced from the same type of feed, regardless of feed rate or whether melted one time or two times, were similar. However, there was a differ ence in the number of inclusions depending on the feed components. The number of inclusions increased directly with the carbon content of the ingots analyzed. The samples from dingots were relatively free of inclusions except for the edge which had some large inclusions or voids (Figure 7). The samples from ingots produced from pigots (Figure 8) had more inclusions than did samples from ingots or dingots. Pigot source material also contained large inclusions of voids near the sample edges. The inclusions in the samples of metal produced from ingot feed high in carbon are shown in Figure 9. The edge has a large number of heavily concentrated inclusions as well as some large voids.

\subsection{CHEMICAL IMPURITIES}

The impurities, B, Be, Cd, Cu, Fe, Mo, Ni, P, Si, Sn, Ti, V, and Zn, were either below the limits of detection or showed no decrease in concentration after electron beam melting.

There was a decrease in many of the other impurities when uranium was melted in the electron beam furnace. The extent of purification was dependent upon the concentration in the feed material and the vapor pressure of the particular species. A summary of the chemical analyses appearing in Table I is as follows:

\subsubsection{Hydrogen}

The hydrogen concentrations were reduced in all cases. The hydrogen concentration was less in ingots produced at the slower feed rate than in those produced at the faster feed rate, except for the ingots produced from ingot feed material. The hydrogen concentration was also lower in ingots melted two times as compared with ingots melted one time. 


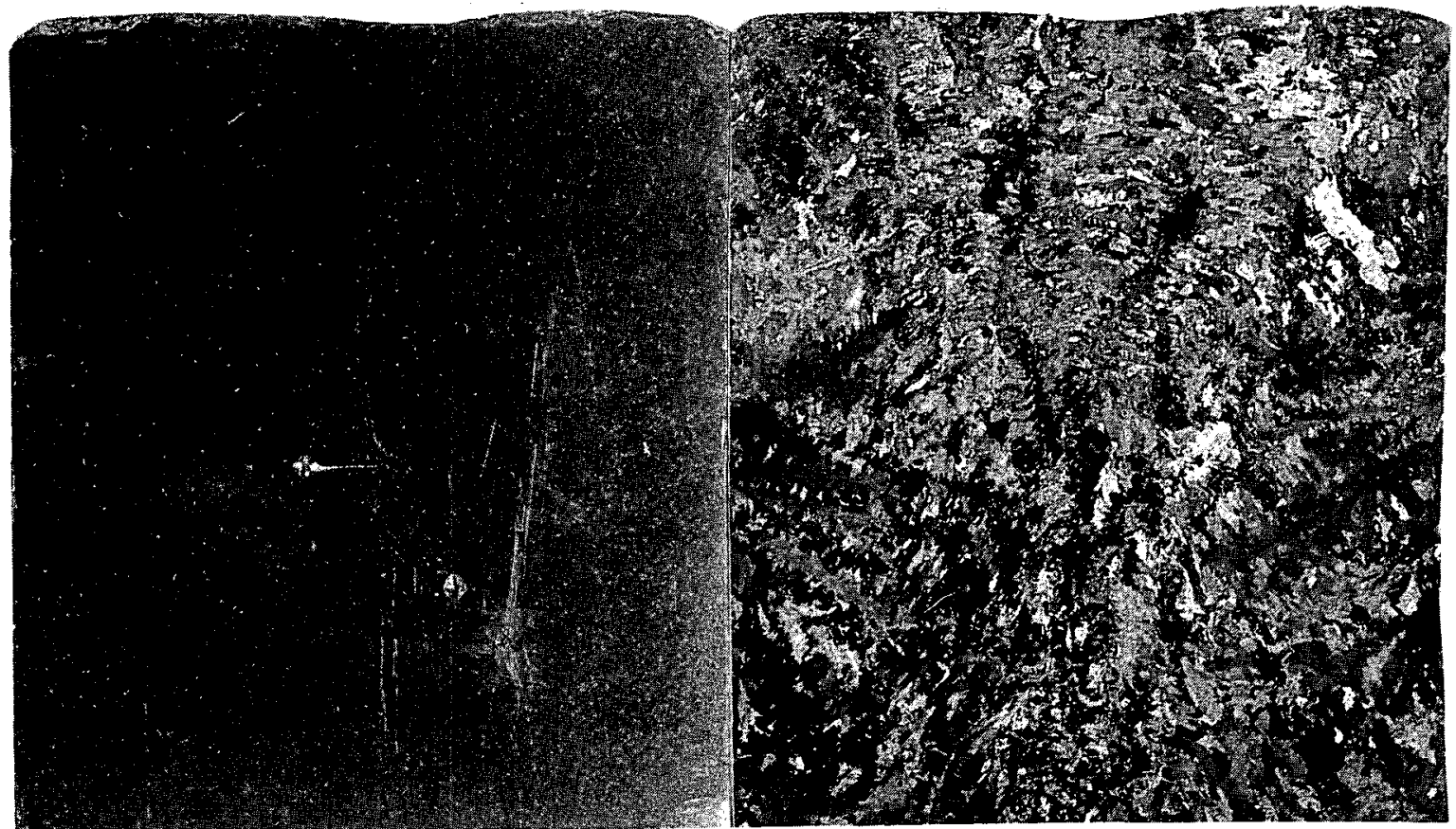

$628 \cdot 32$

$628-52$
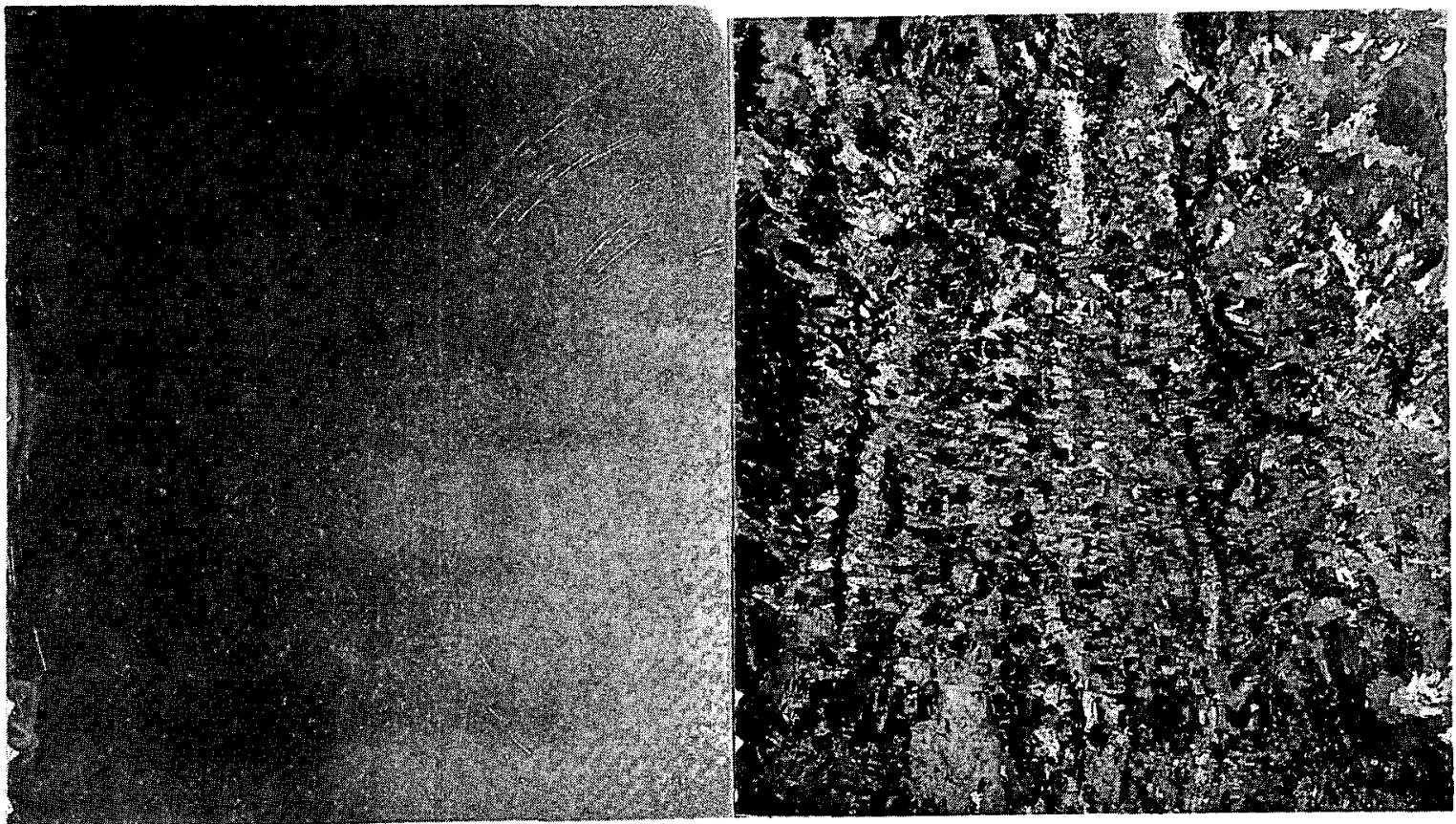

FIGURE 4 Grain Structure and Inclusions in Longitudinal Center Sections of ElectronBeam-Melted Dingot Uranium (IX) 

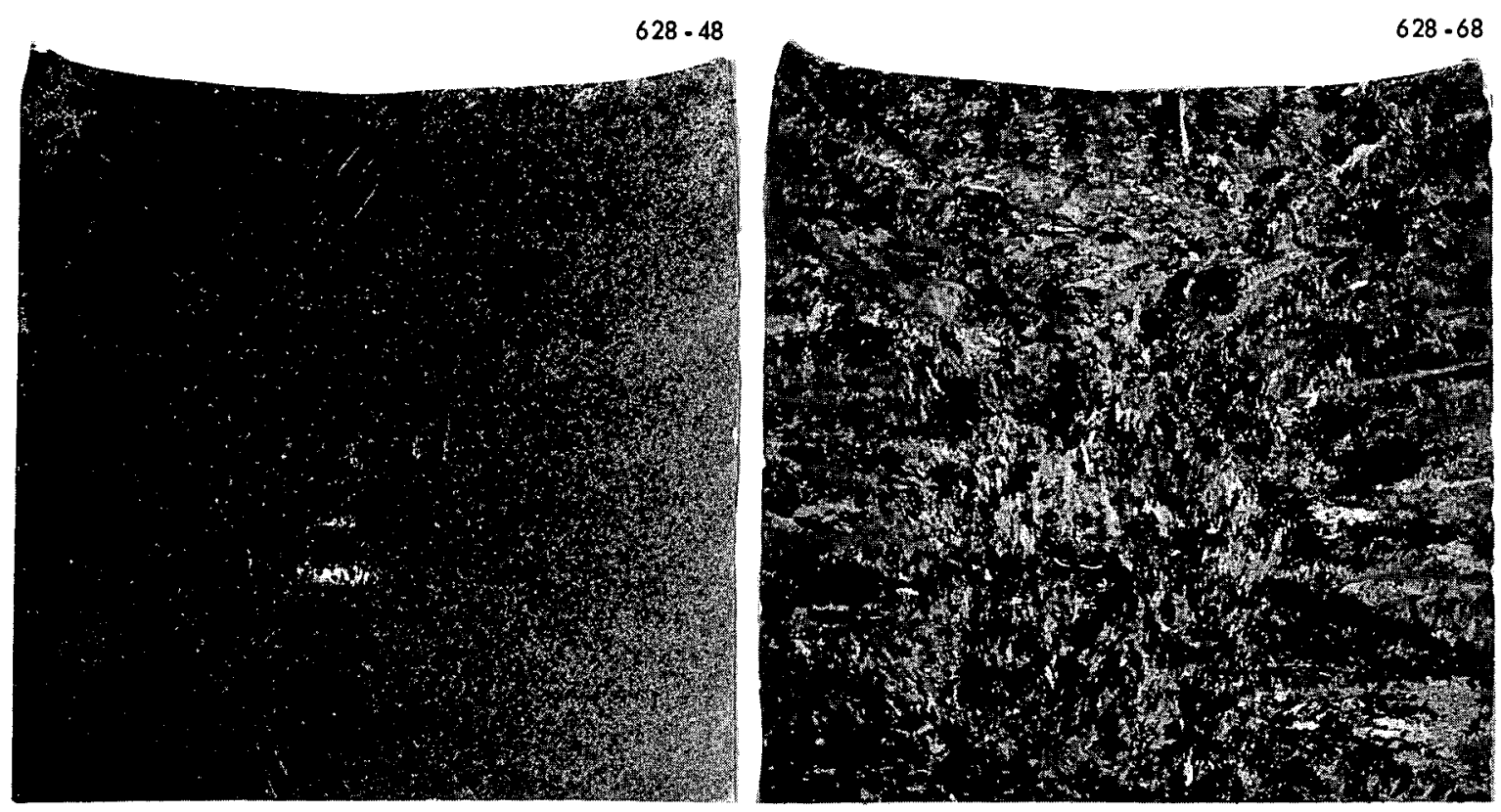

$628 \cdot 39$

$628 \cdot 59$
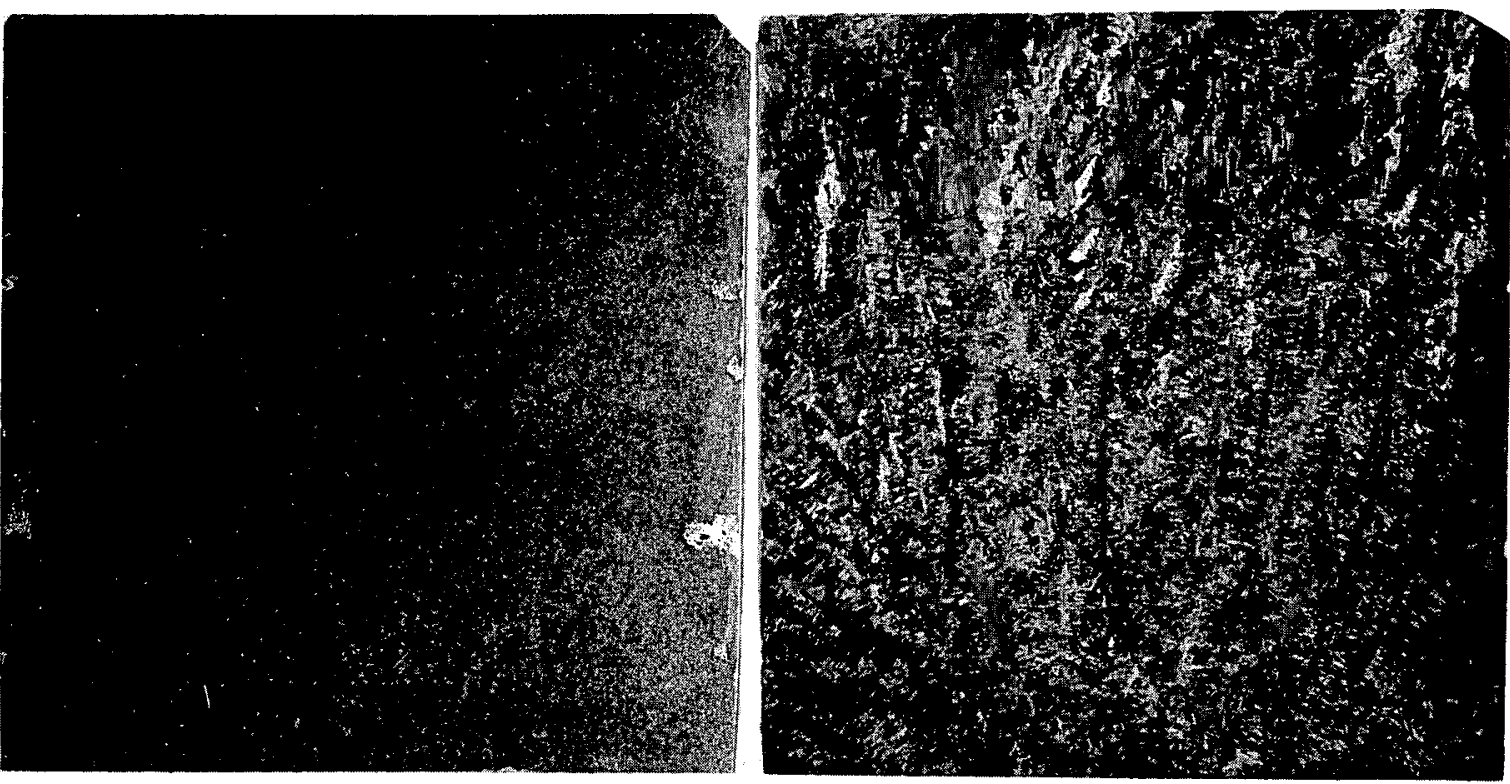

FIGURE 5 Grain Structure and Inclusions in Longitudinal Center Sections of ElectronBeam-Melted Pigot Uranium (IX) 
$628-44$

$628 \cdot 64$
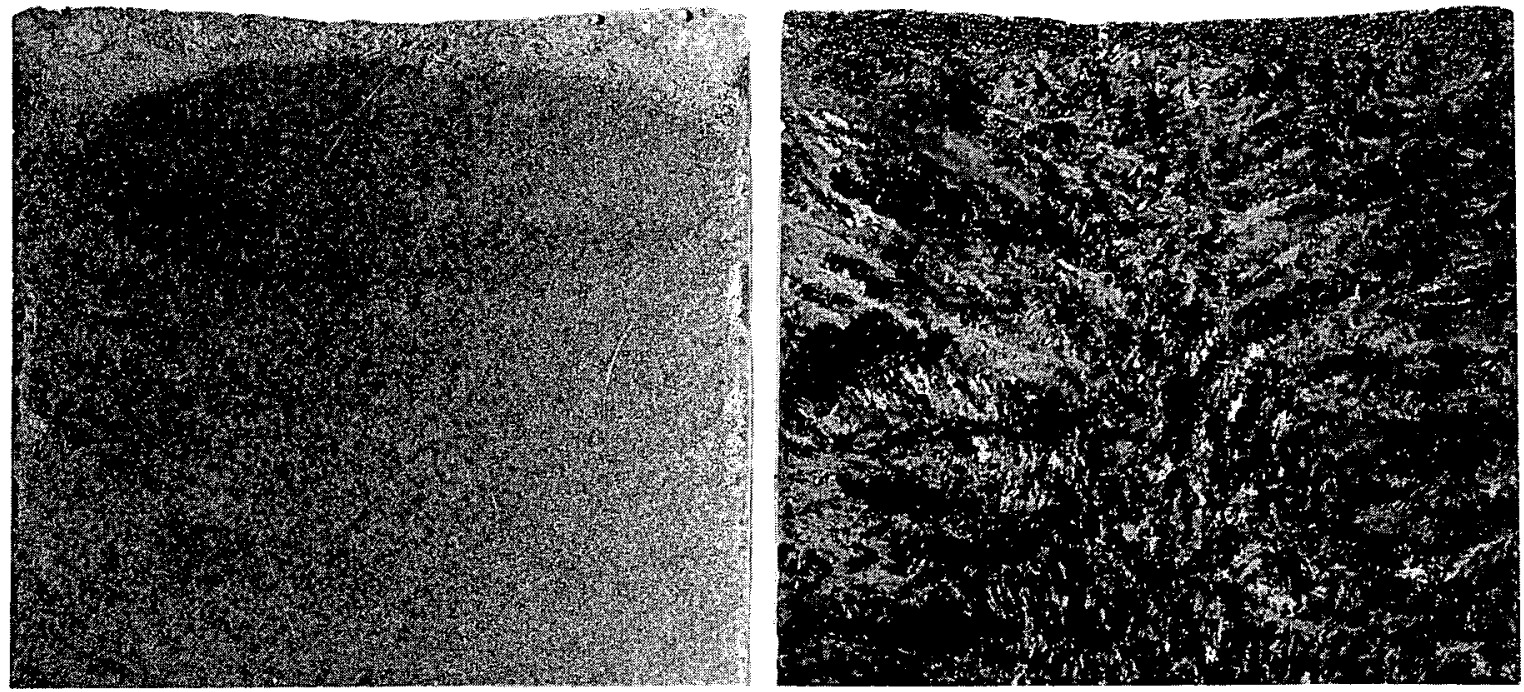

$628 \cdot 35$

$628 \cdot 55$
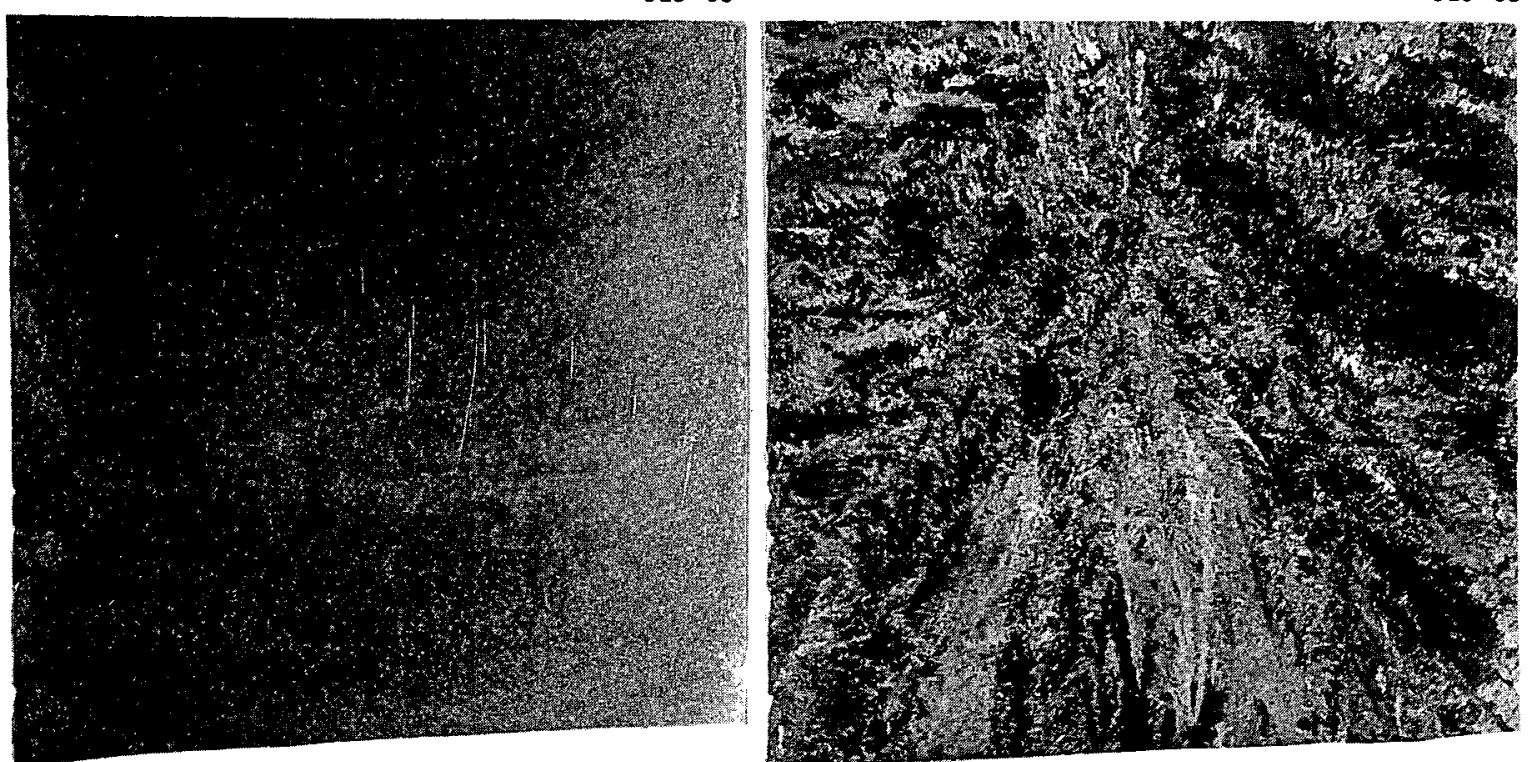

FIGURE 6 Grain Structure and Inclusions in Longitudinal Center Sections of ElectronBeam-Melted Ingot Uranium (1X) 



FIGURE 7 Edge and Center Inclusions of Electron-Beam-Mel ted Dingot Uranium (100X) 

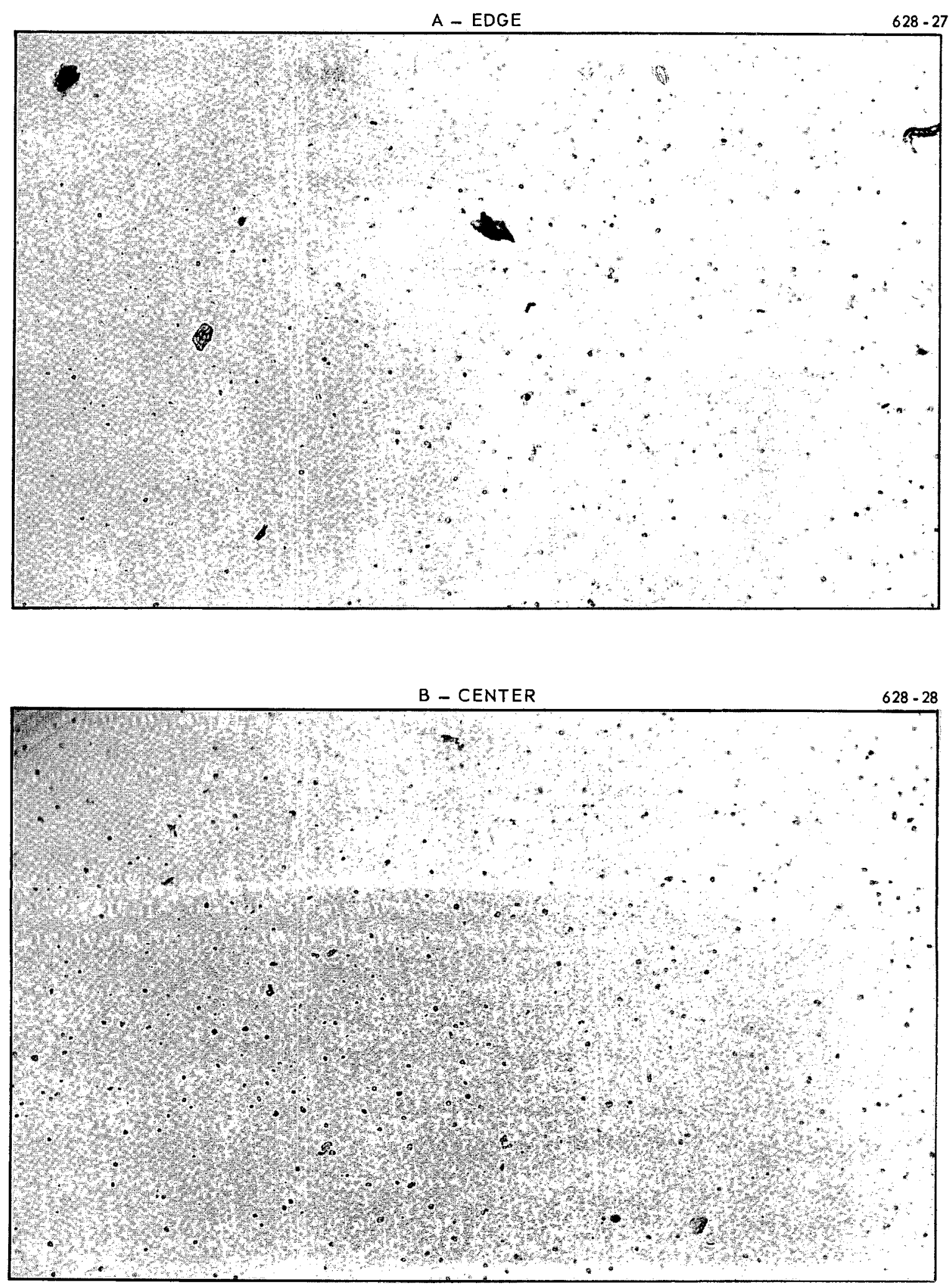

FIGURE 8 Edge and Center Inclusions of Electron-Beam-Melted Pigot Uranium (100X) 




B - CENTER

$628-20$

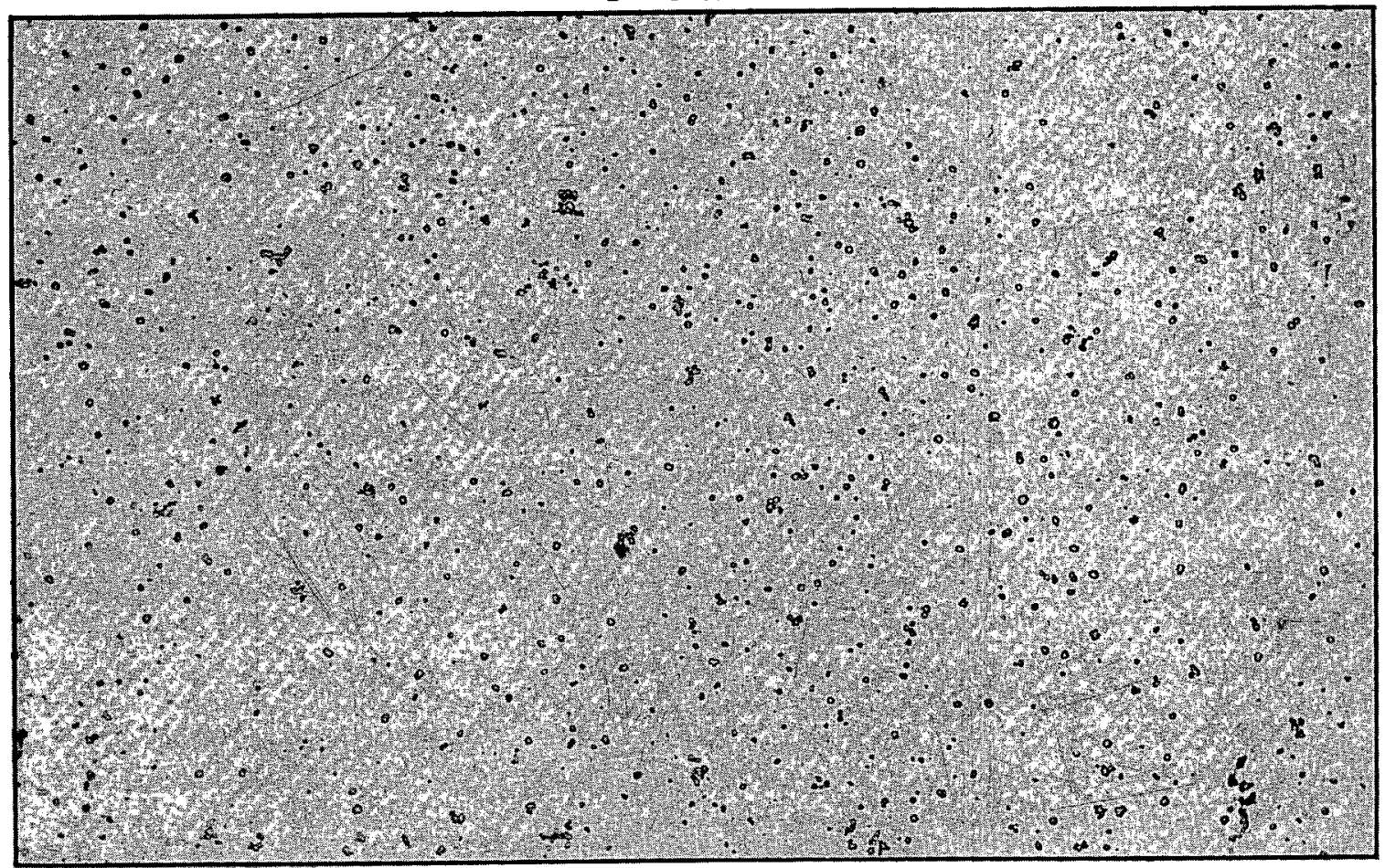

FIGURE 9 Edge and Center Inclusions of Electron-Beam-Melted Ing ot Uranium (100X) 


\subsubsection{Nitrogen}

The nitrogen determinations of the samples indicate that there was a decrease in the nitrogen concentration when the feed material was relatively high in nitrogen (over $100 \mathrm{ppm}$ ). The feed that was low in nitrogen (20 to $30 \mathrm{ppm}$ ) showed little evidence that the nitrogen concentration was decreased. The average nitrogen concentration in the bottom, center, and top samples of the ingots produced from ingot feed material high in nitrogen (112 ppm) was 42, 63, and $751 \mathrm{ppm}$ respectively.

\subsubsection{Oxygen}

The oxygen concentration decreased approximately $50 \%$ in one case; however, the mechanism of deoxidation is not clear.

\subsubsection{Carbon and Zirconium}

Carbon was the same in the electron-beam-melted metal as in the feed material in the two cases in which there was no zirconium in the feed. However, in the third case (ingot feed material source), the carbon and zirconium concentration was less in the electron-beam-melted metal than in the feed material. There was also a similar segregation pattern of carbon and zirconium in the ingots as follows:

\begin{tabular}{|c|c|c|c|}
\hline & \multicolumn{3}{|c|}{ Average Analyses (ppm) } \\
\hline & Bottom & Middle & Top \\
\hline Carbon & 670 & 687 & 1590 \\
\hline Zirconium & 29 & 59 & 363 \\
\hline
\end{tabular}

Because zirconium is a carbon scavenger, it is believed that the zirconium carbides formed and segregated as the feed was being melted by floating on top of the liquid pool.

\subsubsection{Aluminum, Chromium, Magnesium, Manganese, and Lead}

The concentration of all five of these impurities decreased in the metal melted in the electron beam furnace. The mechanism of purification was probably that of volatilization of the metallic elements in an atmosphere of lower pressure than their respective vapor pressures. 
$-26-$

$\bullet$ 


\section{CONCLUSIONS}

Electron beam melting reduces many of the contaminants normally found in uranium and, hence, has a beneficial effect on metal quality. In this test, however, the full potential of the process was not realized because the metal solidified rapidly from a small, shallow pool. To achieve maximum purification at the low furnace pressures obtainable, $10^{-4}$ to $10^{-5}$ torr, the pool of molten metal should be as large and as deep as possible, and the temperature of the molten metal should be higher. It is believed that the maximum melting rate used in this test ( $22 \mathrm{in.} / \mathrm{min}$ ) could be maintained even if the ingot diameters were increased.

Many impurities such as aluminum, chromium, magnesium, manganese, and lead apparently volatilized from the melt. Carbon and zirconium, where both were present, are thought to have formed zirconium carbides which floated to the top of the liquid pool. Similarly, when the nitrogen concentration was high, uranium nitrides formed and floated to the top. This segregation of certain impurities at the top of the melt would make possible their removal by cropping the top of the solidified ingot.

\section{REFERENCES}

${ }^{1}$ H. M. Eikenberry, R. B. Steck, and D. DeTrou. Effects of Furnace Pressure and Feed Material on Uranium Ingot Quality, USAEC Report NLCO-831. December 1, 1960.

${ }^{2}$ H. M. Eikenberry and T. D. Nixon. Consumable-Electrode Arc-Melting of Uranium, USAEC Report NLCO849. June 15, 1962.

${ }^{3}$ H. R. Smith, C. d'A. Hunt, and C. W. Hanks. "Electron-Bombardment Melting," J. Metals, 11: 112.1959. 